\title{
PEMBENTUKAN KATA DALAM BAHASA PERANCIS
}

\author{
oleh Siti Perdi Rahayu \\ FBS Universitas Negeri Yogyakarta
}

\begin{abstract}
Word formation, or morphology, is a process of change in a lexeme, which is the basic material for the formation of a word. One type of word formation is called derivative word formation or derivative morphology, which may produce words of different syntactic roles. Another type of word formation is called inflective word formation or inflective morphology, which produces different units within the same syntactic roles. Both these types of word formation can be found in the French language.

In French, derivative word formation consists of what are here called 1) zero derivation and affixation, 2) composition (or compounding), 3) abbreviation, consisting, in turn, of truncation, initializing (or siglaison), and formation of acronyms (or motsvalises), 4) formation of onomatopoeia, and 5) absorption. The inflective word formation concerns nouns, adjectives, and verbs only. Here any form change in nouns accords with the given gender and number (or nombre) and the forms of adjectives have to agree with the gender and number of their referred nouns but the form change of verbs, besides having to accord with the gender and number of their subjects, is also influenced by the time reference and mode.
\end{abstract}

Key Words: word formation, derivative, inflective

\section{A.Pendahuluan}

Kata adalah morfem atau kombinasi morfem yang dianggap sebagai satuan terkecil yang dapat diujarkan sebagai bentuk bebas (Kridalaksana, 2001:98). Namun perlu diketahui bahwa ada suatu proses morfologis yang menjadikan "bahan dasar" itu berubah menjadi kata. Bahan dasar itulah yang disebut dengan leksem. Perubahan dari leksem menjadi kata inilah yang merupakan kajian utama dalam morfologi. Hal ini sesuai dengan apa yang dinyatakan oleh Kridalaksana (1996:9-10) 
bahwa morfologi dapat dipandang sebagai subsistem linguistik yang berupa proses yang mengubah leksem menjadi kata. Dengan kata lain leksem sebagai satuan leksikal merupakan input dalam proses pengolahan, sedangkan kata sebagai satuan gramatikal merupakan outputnya (ibid:12). Secara ringkas proses itu dapat diformulasikan sebagai berikut.

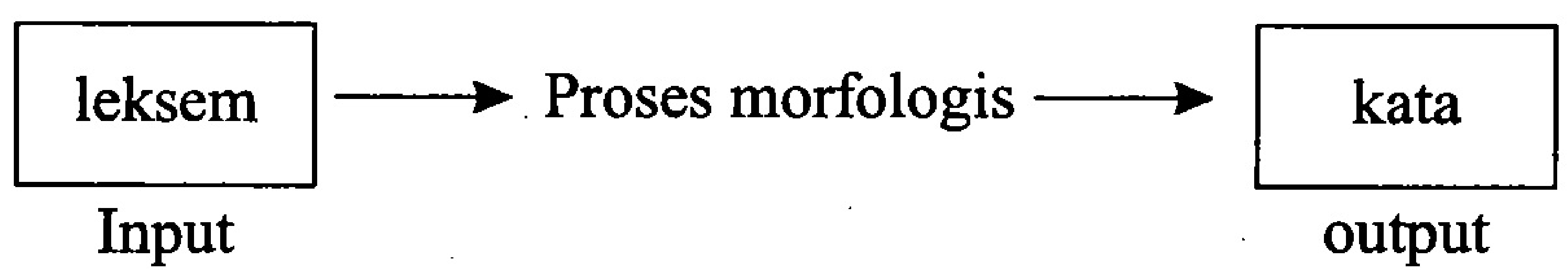

Proses perubahan dari leksem menjadi kata ini termasuk dalam subsistem morfologis leksikal atau morfologi derivatif. Di samping itu terdapat juga proses perubahan kata yang menjadikannya satuan lain yang dapat berperan dalam sintaksis. Proses perubahan ini termasuk dalam morfologi inflektif. Kedua proses pembentukan kata (derivatif dan Inflektif) ini dapat ditemukan dalam pembentukan kata bahasa Prancis.

Garde Tamine (1998:54-55) menjelaskan perbedaan pembentukan kata secara derivatif dan inflektif sebagai berikut.

1) Afiks inflektif tidak akan mengubah kategori kata, sedangkan afiks derivatif akan mengubah kategori dan atau identitas kata.

2) Afiks yang digunakan dalam pembentukan kata secara inflektif merupakan paradigma yang bersifat tertutup, misalnya akhiran dalam konjugasi verba bahasa Prancis, sedangkan afiks yang digunakan dalam pembentukan kata secara derivatif bersifat tak dapat diduga (moins prévisible), sebagai contoh: sufiks eur dapat membentuk nomina yang bermakna pelaku, seperti chanter 'menyanyi' berubah menjadi chanteur ' penyanyi', danser 'menari' berubah menjadi danseur 'penari', tetapi hal ini tidak dapat diterapkan pada semua verba yang berada pada kelompok yang sama, seperti :

arrêter 'menghentikan' tidak akan berubah menjadi *arreteur 
arriver 'datang' tidak akan berubah menjadi * arriveur

3) Afiks derivatif mempunyai fungsi semantis yang dapat menciptakan unit leksikal yang baru, misalnya eur : danser (V) 'menari' berubah menjadi danseur (N) 'penari', sedangkan afiks inflektif tidak dapat menciptakan unit leksikal baru, misalnya $s$ : le petit enfant 'anak kecil' berubah menjadi les petits enfants $(\mathrm{N})$ 'anak-anak kecil'

Perbedaan diatas mengakibatkan adanya klasifikasi pembentukan kata secara derivatif dan secara inflektif. Menurut Blois $(1975: 28)$ proses morfologis atau proses pembentukan kata secara derivatif dalam bahasa Prancis yang termasuk dalam pembentukan kata secara derivatif dapat diklasifikasikan menjadi derivasi zero, afiksasi, komposisi serapan. Sedangkan Grevisse (1969:19) membedakannya menjadi derivasi, komposisi, onomatope dan abreviasi. Klasifikasi yang lain juga disampaikan oleh Gardes-Tamine (1998:73-82), yaitu: derivasi, serapan, komposisi, dan abreviasi. Pengklasifikasian yang terakhir disampaikan oleh Garrie (2001:121-122), yaitu: derivasi, komposisi, abreviasi atau troncation (pemendekan), penyingkatan (siglaison), mot-valise, dan serapan. Pembentukan kata secara inflektif selalu berkaitan dengan kategori nomina, verba dan adjektiva.

Untuk mempermudah pemahaman dalam tulisan ini, akan dijelaskan secara singkat pembentukan kata secara derivatif, yang meliputi: 1) derivasi, 2) komposisi, 3) abreviasi, 4) onomatope, dan 5) serapan, dilanjutkan dengan proses pembentukan kata secara inflektif.

\section{B. Pembentukan Kata Secara Derivatif}

Proses pembentukan kata secara derivatif adalah proses pembentukan kata yang dapat menghasilkan unit leksikal baru yang berkategori dan beridentitas baru.

DIKSI Vol.10, No.2, Juli 2003 


\section{Derivasi}

Proses pembentukan kata dengan derivasi dibedakan menjadi 2 (dua), yaitu: derivasi zero ( derivation impropre) dan afiksasi (derivation propre)

a) Derivasi Zero (derivation impropre)

Derivasi zero adalah proses yang mengubah leksem menjadi kata tanpa perubahan apa-apa. Contoh:

malade (Adj)

sourir (V)

une rose $(N)$

berubah menjadi un malade $(N)$ berubah menjadi le sourire $(\boldsymbol{N})$

charmant (part pré)

berubah menjadi un ruban rose (Adj)

berubah menjadi spectacle charmant (Adj)

durant (p pré)

berubah menjadi durant dix ans (prép)

l'attention $(N)$

berubah menjadi attention! (interj)

il suffit (bentuk verbale) berubah menjadi ça suffit! (interj)

\section{b) Afiksasi (derivation propre)}

Afiksasi adalah proses yang mengubah leksem menjadi kata kompleks. Dalam proses ini leksem dapat berubah bentuknya menjadi kategori baru, sehingga berstatus kata, dan jika sudah berstatus kata, akan berganti kategori, dan juga berubah maknanya. Afiksasi yang terjadi dalam pembentukan kata ini dibedakan menjadi 3 (tiga), yaitu: 1) prefiksasi, 2) sufiksasi dan 3) konfiks (parasynthétique)

\section{1) Prefiksasi}

Prefiks adalah proses pembentukan kata dengan menambahkan afiks di depan atau di sebelah kiri bentuk dasar. Pembentukan kata yang terkait dengan prefiksasi ini tidak akan mengubah kategori kata, tetapi mengubah makna,

a) Prefiks re-; ré-; $\boldsymbol{r}-\quad$ :mengandung makna pengulangan

re + partir berubah menjadi repartir

ré + édition berubah menjadi réédition 
b) Prefiks prés-; post-: menyatakan posisi (ruang atau waktu) "sesudah"

$$
\begin{array}{lll}
\text { après }+ \text { demain } & \text { berubah menjadi } & \text { après-demain } \\
\text { post }+ \text { date } & \text { berubah menjadi } & \text { postdaté }
\end{array}
$$

c) Prefiks avant-; pré-; anté-:

avant + hier berubah menjadi

pré + histoire berubah menjadi

anté + posé berubah menjadi

'sebelum'

d) Prefiks entre-; inter-:

entre + acte berubah menjadi

avant-hier

préhistoire

antéposé

'antara'

inter + national . berubah menjadi

entracte

e) Prefiks mi- : berubah menjadi mi + nuit berubah menjadi

f) Prefiks extra-: extra + ordinaire berubah menjadi

g) Prefiks intra -: intra + musculaire berubah menjadi

h) Prefiks ex-: ex + professeur berubah menjadi

i) Prefiks trans-: international 'di tengah-tengah' minuit 'di luar' extraordinaire 'di dalamnya' intratamusculaire 'tidak lagi/mantan' trans + atlantique berubah menjadi exprofesseur 'antar'

j) Prefiks yang mengandung makna 'berlawanan/ sebaliknya' des + habiller berubah menjadi deshabiller - in+ attaquable berubah menjadi inattaquable il légal berubah menjadi illégal irt réel berubah menjadi irréel

k) Prefiks yang menyatakan intensitas
- extra-: extrafin, extra-souple
- hyper: hypernerveux, hypertension
- super-: supermarché, supercarburant
- ultra-: ultra-rapide 
l) Prefiks yang menyatakan oposisi atau pendukung.

- anti-

anti-aérien

- contre-

contre-attaque

\section{2) Sufiksasi}

Sufiksasi adalah proses pembentukan kata dengan menambahkan afiks di belakang atau di sebelah kanan bentuk dasar. Pembentukan kata dengan menambahkan sufiks dapat 1) mengubah kategori gramatikal, misalnya té-: propre (Adjektiva) $\longrightarrow$ propeté $(N)$, 2) menentukan jenis kata bentukannya, misalnya: - $\underline{\text { ion }}$ berjenis femina, ge berjenis maskulin, 3) menambah makna baru, misalnya: -té: légère $\longrightarrow$ légèreté.

Berikut ini contoh-contoh pembentukan kata dengan sufiksasi.

a) Perubahan dari kategori verba ke kategori nomina

1) Sufiks: -(iss)age dan -(isse) ment

hériter berubah menjadi un héritage

attirer berubah menjadi un atterrissage

enseigner berubah menjadi un enseignement

enrichir berubah menjadi un enrichissement

2) Sufiks: -(i)sion, -(a)tion, -(t)ure

répéter berubah menjadi une répétition

s'evader berubah menjadi une évasion

permettre berubah menjadi une permission

obliger berubah menjadi une obligation

distraire berubah menjadi une distraction

proteger berubah menjadi une protection

déchirer berubah menjadi une déchiture

fermer berubah menjadi une fermeture

3) Sufiks: -eur/-euse, -(a)teur-/trice, -ier/-ière, -ant/-ante, oir/-oire, -(at)aire

vendre berubah menjadi vendeur/vendeuse

battre berubah menjadi batteur/batteuse 


\begin{tabular}{|c|c|c|}
\hline $\begin{array}{l}\text { décorer } \\
\text { cuisinier } \\
\text { sucrer } \\
\text { militer } \\
\text { desherber } \\
\text { fermer } \\
\text { bouillir } \\
\text { contester }\end{array}$ & $\begin{array}{l}\text { berubah menjadi } \\
\text { berubah menjadi } \\
\text { berubah menjadi } \\
\text { berubah menjadi } \\
\text { berubah menjadi } \\
\text { berubah menjadi } \\
\text { berubah menjadi } \\
\text { berubah menjadi }\end{array}$ & $\begin{array}{l}\text { décorateur/décoratrice } \\
\text { cuisinier/cuisinière } \\
\text { sucrier } \\
\text { militant/militante } \\
\text { desherbant } \\
\text { fermoir } \\
\text { bouilloire } \\
\text { contestataire }\end{array}$ \\
\hline
\end{tabular}

b) Pembentukan dari kategori nomina ke kategori nomina lain :

1) Sufiks:-eur berubah menjadi -orat; -aire berubah menjadi -ariat professeur berubah menjadi professorat secrétaire berubah menjadi secrétariat

2) Sufiks: -ie berubah menjadi -ien/-ienne pharmacie berubah menjadi pharmacien technique berubah menjadi technicien/ technicienne

3) Sufiks: -aire; - iste; -ier/ière

\begin{tabular}{|c|c|c|}
\hline $\begin{array}{l}\text { disque } \\
\text { modèle } \\
\text { couture }\end{array}$ & $\begin{array}{l}\text { berubah menjadi } \\
\text { berubah menjadi } \\
\text { berubah meniadi }\end{array}$ & $\begin{array}{l}\text { disquaire } \\
\text { modèliste } \\
\text { conturier/ couturière }\end{array}$ \\
\hline Sufiks: -ier & & coutarler conchere \\
\hline $\begin{array}{l}\text { fruit } \\
\text { coco } \\
\text { Sufiks: -ée }\end{array}$ & $\begin{array}{l}\text { berubah menjadi } \\
\text { berubah menjadi }\end{array}$ & $\begin{array}{l}\text { fruitier } \\
\text { cocotier }\end{array}$ \\
\hline $\begin{array}{l}\text { cuillère } \\
\text { bouche } \\
\text { ufiks: -ette, -et }\end{array}$ & $\begin{array}{l}\text { berubah menjadi } \\
\text { berubah menjadi }\end{array}$ & $\begin{array}{l}\text { cuillerée } \\
\text { bouchée }\end{array}$ \\
\hline $\begin{array}{l}\text { maison } \\
\text { garçon }\end{array}$ & $\begin{array}{l}\text { berubah menjadi } \\
\text { berubah menjadi }\end{array}$ & $\begin{array}{l}\text { maisonnette } \\
\text { garçonnet }\end{array}$ \\
\hline
\end{tabular}

DEKSI Vol.10, No.2, Juli 2003 
7)Sufiks: -eur

berubah menjadi

-ard chauffeur berubah menjadi chauffard

c)Perubahan dari kategori Adjektiva menjadi kategori nomina

1) Sufiks: -(i) té légère immense berubah menjadi

légèreté

2)Sufiks: -(er) ie $\begin{array}{lll}\text { jalouse } & \text { berubah menjadi } & \text { jalousie } \\ \text { étourdie } & \text { berubah menjadi } & \text { étourderie }\end{array}$

3)Sufiks: -eur

$\begin{array}{lll}\text { blanche } & \text { berubah menjadi } & \text { blancheur } \\ \text { grande } & \text { berubah menjadi } & \text { grandeur }\end{array}$

4)Sufiks: -ise bête berubah menjadi bêtise

5)Sufiks: -( $t$ ) esse, $-(r)$ esse polie berubah menjadi politesse sèche berubah menjadi sécheresse

6)Sufiks: -(i)tude inuiète berubah menjadi inquiètude seule berubah menjadi solitude

7)Sufiks:

$\begin{array}{lll}\text {-ante } & \text { berubah menjadi } & \text {-ance } \\ \text {-ente } & \text { berubah menjadi } & \text {-ence } \\ \text { élégante } & \text { berubah menjadi } & \text { élégance } \\ \text { violent } & \text { berubah menjadi } & \text { violence }\end{array}$

d) Perubahan dari kategori nomina/ Adjektiva menjadi kategori nomina

1) Sufiks: -isme, -iste $\begin{array}{lcl}\text { social } & \text { berubah menjadi } & \begin{array}{l}\text { socialisme } \\ \text { socialiste } \\ \text { réformisme }\end{array} \\ \text { reforme } & \text { berubah menjadi } & \end{array}$ 
réformiste

e) Perubahan dari kategori nomina menjadi kategori Adjektiva

1) Sufiks: -aV-ale, -eV -elle structure berubah menjadi structural structurale personne berubah menjadi personnelpersonnelle

2) Sufiks: -ien/-ienne Italie berubah menjadi italien/italienne Indonésie berubah menjadi indonésien/indonésienne

3) Sufiks: -ain/-aine Amérique berubah menjadi américain/américaine

4) Sufiks: -in/-ine enfant berubah menjadi

5) Sufiks: -ais/-aise Rennes berubah menjadi enfantin/enfantine

6) Sufiks: -ois/ -oise Lille berubah menjadi Chine berubah menjadi

7) Sufiks: $-e u x /-e u s e$ nuage berubah menjadi rennais/rennaise

Sufiks: -ier/-ière lait berubah menjadi laitier/laitière

9) Sufiks: -if/-ive imagination berubah menjadi imaginatif/imaginative 10) Sufiks: $-e ́ l-e ́ e$ chocolat berubah menjadi sucre berubah menjadi chocolatél chocolatée 1)Sufiks: $-w /-u e$ barbe berubah menjadi moustache berubah menjadi lillois/illoise chinois/chinoise nuageux/ nuageuse 2)Sufiks:-aire lune berubah menjadi lunaire

13)Sufiks: -oire 
obligation berubah menjadi obligatoire

14)Sufiks: -ique

méthode berubah menjadi méthodique

16)Sufiks: -esque

roman berubah menjadi romanesque

f) Perubahan dari kategori verba menjadi kategori Adjektiva

1) Sufiks: -able, -ible

boire (buvons) berubah menjadi buvable

lire (lisons) berubah menjadi lisible

g) Perubahan dari kategori nomina menjadi kategori verba

Sufiks: $-e r, a+$ nom + ir

$\begin{array}{lll}\text { téléphone } & \text { berubah menjadi } & \text { téléphoner } \\ \text { terre } & \text { berubah menjadi } & \text { atterrir }\end{array}$

h) Perubahan dari kategori Adjektiva menjadi kategori verba

1)Sufiks: -ir

$\begin{array}{lll}\text { rouge } & \text { berubah menjadi } & \text { rougir } \\ \text { grand } & \text { berubah menjadi } & \text { grandir }\end{array}$

2) $a$ (prefiks) + Adjektiva + -ir atau er; $\dot{e}($ prefiks $)+$ Adjektiva + ir

grand berubah menjadi agrandir

large berubah menjadi élargir

3)Sufiks: -iser, -ifier

égal berubah menjadi égaliser

simple berubah menjadi simplifier

i) Perubahan dari kategori Adjektiva menjadi kategori Adverbia Sufiks: -ment

légère berubah menjadi légèrement

douce berubah menjadi doucement

j) Perubahan dari kategori Adjektiva menjadi kategori Adjektiva dengan makna peyoratif 
Sufiks: -âtre

rouge berubah menjadi rougeâtre

k) Sufiks yang berasal dari Yunani, antara lain:

-logi: lexique berubah menjadi

-logue: psychologie berubah menjadi

-logiste: minéralogie berubah menjadi

-métrie

-graphie

-graphe berubah menjadi

berubah menjadi

berubah menjadi lexicologie

psychologue minéralogiste

géométrie

géographie

géographe

cinématographe

\section{3) Konfiks (Parasynthétique)}

Konfiks (parasynthétique) adalah pembentukan kata dengan menambahkan prefiks dan sufiks secara bersama-sama pada bentuk dasarnya. Contoh:

im- + par(er)+ able berubah menjadi imparable tidak mungkin menjadi

*impar /

*parable

dé-tcouraget-er berubahmenjadi décourager tidak mungkin menjadi *découragel

*courager

a-tlunet-ir berubah menjadi alunir tidak mungkin menjadi

*lunir/

*alune

em-+barquet-er berubah menjadi embarquetidak mungkin menjadi *barquer/

*embarque

dés-therbet-er berubah menjadi désherber tidak mungkinmenjadi

*désherbe

*herber 


\section{Komposisi (Pemajemukan)}

Komposisi atau pemajemukan adalah proses penggabungan dua leksem atau lebih yang membentuk kata baru. Unsur inti (une tête) kata majemuk dalam bahasa Prancis pada umumnya adalah kata yang berada di sebelah kiri.

a) Gabungan Nomina + Nomina menghasilkan Nomina une wagon restaurant

un whisky-soda

une peintre-tapissier

un chien-loup

etc

b) Gabungan Nomina + Adjektiva menghasilkan Nomina un coffre fort

une vinagre

un chateau neuf

une basse-cour

c) Gabungan verba + Nomina menghasilkan Nomina un tire-bouchon

un réveille-matin

un essuie-glace

un gratte-ciel

d) Gabungan Verba + Verba menghasilkan Nomina un laissez-passez

va-et-vien

pausse-pousse

e) Gabungan Verba + Adv menghasilkan Nomina un passe-partout

f) Gabungan Adj + Adj menghasilkan Adj sourd-muet

g) Gabungan Adv + Adj + Adj menhasilkan Adj avant-coureur 


\section{Abreviasi}

Pemendekan (abreviasi) adalah proses penanggalan satu atau beberapa bagian leksem atau kombinasi leksem, sehingga jadilah bentuk baru yang berstatus kata. Abreviasi adalah istilah umum yang meliputi troncation, singkatan (siglaison) dan akronim (mot-valise). Bentukbentuk abreviasi dalam bahasa Prancis dapat dilihat pada contoh-contoh berikut ini:

a) Troncation

automobile

taximètre

métropolitain

cinématographe

dictionnaire

berubah menjadi

berubah menjadi

auto

berubah menjadi

taxi

berubah menjadi

métro

Penyingkatan (Siglaison)

SEITA : Société d'Exploitation Industrielle des Tabacs et des Allumettes

TGV : Train à Grande Vitesse

CGT : Confédération Général du Travail

\section{HLM : Habitation à Loyer Modéré}

c) Akronim atau Mots-Valises

Akronim atau mots-valises dibentuk dengan cara mengambil suku kata pertama dari kata pertama dan (sebagian besar) suku kata terakhir dari kata kedua (Certa, -: 51) Misalnya:

Motocar et Hôtel berubah menjadi Organisation de Secours berubah menjadi

motel

Belgique,

Nederland et Luxemburg Confiture, compote

berubah menjadi ciné

Français et anglais berubah menjadi Benelux berubah menjadi confipote franglais 


\section{Onomatope}

Onomatope adalah kata-kata yang dihasilkan dari tiruan atau kemiripan bunyi-bunyi tertentu. (Grevisse, 1969: 26)

Misal:

Cocorico $\longrightarrow$ berasal dari bunyi ayam berkokok

Cri-cri $\longrightarrow$ berasal dari bunyi jeritan

Tictac $\longrightarrow$ berasal dari detak jarum jam

Frou-frou $\longrightarrow$ berasal dari bunyi kain/ bulu yang bergesekan

\section{Kata Serapan}

Kata serapan adalah kosa kata bahasa Prancis yang berasal dari negara lain.

Dari Arab : café, sirop, zéro, petit, bled, le souk, chiffre, hasard

Dari Italie : balcon, colonel, piano, des spaghettis, dolce vita, bambin, bravo

Dari Inggris : bouledoque, standard, planning., bungalow, un steak, paguebot

Dari Spanyol : un torero, un macho, azur, bizarre

Dari Jerman : chic, vampire

\section{Pembentukan Kata Secara Inflektif}

Pembentukan kata yang tidak akan mengubah kategori kata ini termasuk dalam kajian morfologi inflektif, yaitu pembentukan kata yang hanya terjadi pada kategori kata nomina, adjektiva, dan verba (GardeTamine, 1988:58). Berikut ini akan dijelaskan pembentukan kata pada kategori-kategori kata tersebut.

\section{Nomina}

Pembentukan kata secara inflektif yang berkaitan dengan nomina ini menyangkut 2 (dua) hal, yaitu jenis (genre) dan jumlah 
(nombre). Jenis (genre) meliputi jenis maskula dan femina. Jenis nomina yang bersangkutan dengan orang dibedakan berdasarkan jenis kelamin, misalnya le père 'ayah', dan la mère 'ibu'. Walaupun ada juga nomina yang berjenis femina, tetapi secara referensial berjenis maskula, contoh: ordonnance(f) 'urutan/ peraturan', vigie(f) 'kelasi', estafette(f) 'kurir', clarinette(f) 'klarinet', dan sebaliknya ada pula nomina berjenis maskula tetapi secara referensial berjenis femina, misalnya mannequin(m) 'boneka peraga busana', cordon-bleu(m) 'ahli masak'. Untuk nomina yang berkaitan dengan benda tak hidup (inanimé) penentuan jenisnya bersifat arbitrer dan tak dapat diduga (imprévisible). Pembentukan nomina berdasarkan jenisnya secara lengkap dapat dilihat pada tabel 1 dan 2 berikut ini.

Tabel 1. Pembentukan Nomina Jenis Femina Beraturan

\begin{tabular}{|l|l|l|}
\hline Nomina Maskula & Nomina Femina & \multicolumn{1}{c|}{ Aturan } \\
\hline $\begin{array}{l}\text { un ami } \\
\text { un candidat }\end{array}$ & $\begin{array}{l}\text { une amie } \\
\text { une candidate }\end{array}$ & $\begin{array}{l}\text { Aturan Umum: nomina femina } \\
\text { dibentuk dengan menambahkan } \\
\text { e pada nomina maskulanya. }\end{array}$ \\
\hline $\begin{array}{l}\text { un artiste } \\
\text { un nègre }\end{array}$ & $\begin{array}{l}\text { une artiste } \\
\text { une négresse }\end{array}$ & $\begin{array}{l}\text { Nomina maskula yang berakhiran } \\
\text { e pada nomina feminanya tidak } \\
\text { berubah, kecuali ada beberapa } \\
\text { nomina yang harus bersufiks esse }\end{array}$ \\
\hline $\begin{array}{l}\text { un époux } \\
\text { un vengeur } \\
\text { un acteur }\end{array}$ & $\begin{array}{l}\text { une épouse } \\
\text { une danseuse } \\
\text { une vengeresse }\end{array}$ & $\begin{array}{l}\text { Nomina maskula yang berakhiran } \\
\text { oux atau -eur akan berakhiran } \\
\text { ouse atau eusse pada nomina } \\
\text { feminanya, kecuali -eur berubah } \\
\text { menjadi berubah menjadi } \\
\text { berakhiran -eresse, dan sebagian } \\
\text { besar nomina maskula berakhiran } \\
\text { teur pada nomina feminanya } \\
\text { akan berakhiran -trice }\end{array}$ \\
\hline
\end{tabular}

DIKSI Vol.10, No.2, Juli 2003 


\begin{tabular}{|l|l|l|}
\hline un fermier & une fermière & $\begin{array}{l}\text { Nomina maskula berakhiran er } \\
\text { pada nomina feminanya } \\
\text { berakhiran -ère }\end{array}$ \\
\hline $\begin{array}{l}\text { Gabriel } \\
\text { le jumeau }\end{array}$ & $\begin{array}{l}\text { Gabrielle } \\
\text { la jumelle }\end{array}$ & $\begin{array}{l}\text { Nomina maskula berakhiran el } \\
\text { dan -eau pa nomina feminanya } \\
\text { berakhiran -elle }\end{array}$ \\
\hline $\begin{array}{l}\text { le gardien } \\
\text { un Lion } \text { cousin } \\
\text { un faisan } \\
\text { un paysan }\end{array}$ & $\begin{array}{l}\text { une gardienne } \\
\text { une lionne } \\
\text { une cousine } \\
\text { une faisane }\end{array}$ & $\begin{array}{l}\text { Nomina maskula berakhiran ien } \\
\text { dan ion pada nomina feminanya } \\
\text { berubah menjadi nne. Namun } \\
\text { nomina maskula berakiran in } \\
\text { dan -an pada nominanya tinggal } \\
\text { menambahkan e }\end{array}$ \\
\hline $\begin{array}{l}\text { un rat } \\
\text { un chat }\end{array}$ & $\begin{array}{l}\text { une rate } \\
\text { une chatte }\end{array}$ & $\begin{array}{l}\text { Nomina maskula berakhiran t } \\
\text { bentuk nomina feminanya tinggal } \\
\text { menambahkan e, namun ada yang } \\
\text { harus menambahkan -te }\end{array}$ \\
\hline $\begin{array}{l}\text { un loup } \\
\text { un veuf }\end{array}$ & $\begin{array}{l}\text { une louve } \\
\text { une veuve }\end{array}$ & $\begin{array}{l}\text { Nomina maskula berakhiran p } \\
\text { atau f pada bentuk nomina f } \\
\text { eminanya berubah berakhiran -ve }\end{array}$ \\
\hline
\end{tabular}


Tabel 2. Pembentukan Nomina Takberaturan Berdasarkan Jenis

\begin{tabular}{|c|c|c|c|}
\hline $\begin{array}{c}\text { Nomina } \\
\text { Maskula }\end{array}$ & $\begin{array}{l}\text { Nomina } \\
\text { Femina }\end{array}$ & $\begin{array}{l}\text { Nomina } \\
\text { Maskula }\end{array}$ & $\begin{array}{l}\text { Nomina } \\
\text { Femina }\end{array}$ \\
\hline roi & reine & taureau & vache \\
\hline mari & femme & lévrier & levrette \\
\hline gendre & bru & empereur & impératrice \\
\hline$d u c$ & duchesse & fils & fille \\
\hline docteur & doctoresse & neveu & nièce \\
\hline bouc & chèvre & frère & saur \\
\hline jars & oie & oncle & tante \\
\hline sanglier & laie & cerf & biche \\
\hline canard & cane & veau & génisse \\
\hline serviteur & servani & singe & guenon \\
\hline parrain & marraine & mulet & mule \\
\hline dieu & déesse & lièvre & hase \\
\hline pair & pairesse & bélier & brebis \\
\hline neros & heroine & & \\
\hline
\end{tabular}

Jumlah (nombre) meliputi jumlah tunggal (singulier) dan jamak (pluriel). Secara garis besar, jumlah tunggal menggambarkan jumlah suatu nomina satu, sedangkan jumlah jamak menggambarkan jumlah suatu nomina lebih dari satu, misalnya un chat 'seekor kucing' adalah jumlah tunggal dan des chats 'kucing-kucing' adalah jumlah jamak. Namun begitu, ditemukan pula nomina berjumlah tunggal, tetapi mengandung makna jamak. Nomina jenis ini disebut nomina kolektif ( noms collectifs) (Jouannon, 1984: 29), misalnya le bétail, la foule, la flotte française d.s.t. Pembentukan nomina berdasarkan jumlah dapat dilihat pada tabel 3 dan 4 berikut ini. 
Tabel 3. Pembentukan Nomina Berdasarkan Jumlah

\begin{tabular}{|c|c|c|}
\hline Nomina Tunggal & Nomina Jamak & Aturan \\
\hline $\begin{array}{l}\text { un ennui } \\
\text { un lit }\end{array}$ & $\begin{array}{l}\text { des ennuis } \\
\text { des lits }\end{array}$ & $\begin{array}{l}\text { Aturan Umum: bentuk } \\
\text { nomina jamak dibentuk } \\
\text { dengan menambahkan -s }\end{array}$ \\
\hline $\begin{array}{l}\text { n bois } \\
\text { une noix } \\
\text { un nez }\end{array}$ & $\begin{array}{l}\text { des bois } \\
\text { des noix } \\
\text { des nez }\end{array}$ & $\begin{array}{l}\text { Nomina tunggal berakhiran } \mathbf{s} \text {, } \\
-\mathbf{x} \text {, dan }-\mathbf{z} \text { tidak mengalami } \\
\text { perubahan pada bentuk } \\
\text { jamaknya }\end{array}$ \\
\hline $\begin{array}{l}\text { un cheval } \\
\text { un chacal }\end{array}$ & $\begin{array}{l}\text { des chevaux } \\
\text { des chacals }\end{array}$ & $\begin{array}{l}\text { Nomina tunggal berakhiran } \\
\text { al pada bentuk jamaknya } \\
\text { berubah berakhiran aux, } \\
\text { kecuali nomina bal, } \\
\text { carnaval, cérémonial, } \\
\text { chacal, yang mengikuti } \\
\text { aturan umum. }\end{array}$ \\
\hline $\begin{array}{l}\text { un veau } \\
\text { un étau } \\
\text { un feu } \\
\text { un pneu }\end{array}$ & $\begin{array}{l}\text { des veaux } \\
\text { des étaux } \\
\text { des feux } \\
\text { des pneus }\end{array}$ & $\begin{array}{l}\text { Nomina tunggal berakhiran } \\
\text { eau, -au, dan eu bentuk } \\
\text { jamaknya tinggal } \\
\text { menambahkan } \mathbf{x} \text {, kecuali } \\
\text { nomina landau, sarrau, } \\
\text { pneu bentuk jamaknya } \\
\text { dengan ditambah -s }\end{array}$ \\
\hline $\begin{array}{l}\text { un cou } \\
\text { un chou }\end{array}$ & $\begin{array}{l}\text { des cous } \\
\text { des chous }\end{array}$ & $\begin{array}{l}\text { Nomina tunggal berakhiran } \\
\text { ou biasanya bentuk } \\
\text { jamaknya berakhiran ous, } \\
\text { kecuali nomina hibou, } \\
\text { joujou, bijou yang bentuk } \\
\text { jamaknya berakhiran -x }\end{array}$ \\
\hline
\end{tabular}




\begin{tabular}{|c|c|c|}
\hline $\begin{array}{l}\text { un rail } \\
\text { un travail }\end{array}$ & $\begin{array}{l}\text { des rails } \\
\text { des travaux }\end{array}$ & $\begin{array}{l}\text { Nomina tunggal berakhiran } \\
\text { ail bentuk jamaknya } \\
\text { berakhiran ails, kecuali } \\
\text { bail, émail, travail, vantail, }\end{array}$ \\
\hline $\begin{array}{l}\text { L'aieul } \\
\text { le ciel } \\
\text { l'oeil }\end{array}$ & $\begin{array}{l}\text { les aïeux } \\
\text { les cieux } \\
\text { les yeux }\end{array}$ & $\begin{array}{l}\text { Nomina aïeul, cieul, oeil } \\
\text { merupakan nomina } \\
\text { takberaturan; tetapi kita } \\
\text { mnegatakan bisaïeul, } t \\
\text { riaïeul, dan aïeul yang } \\
\text { bermakna grands-parents, } \\
\text { ciels dalam ciels de lit dan } \\
\text { oeils dalam oeils-de- bouf. }\end{array}$ \\
\hline un référendum & des référendums & $\begin{array}{l}\text { Aturan Umum: bentuk } \\
\text { nomina jamak dibentuk } \\
\text { dengan menambahkan s }\end{array}$ \\
\hline $\begin{array}{l}\text { un maximum } \\
\text { un dilettante }\end{array}$ & $\begin{array}{l}\text { des maxima } \\
\text { atau des maximums } \\
\text { des dilettantes } \\
\text { atau dilettanti }\end{array}$ & $\begin{array}{l}\text { Beberapa nomina tertentu } \\
\text { tetap mempertahankan } \\
\text { bentuk aslinya daripada } \\
\text { mengikuti aturan umum } \\
\text { pembentukan jamak dalam } \\
\text { nomina bahasa Prancis }\end{array}$ \\
\hline $\begin{array}{l}\text { un gentleman } \\
\text { un lie }\end{array}$ & $\begin{array}{l}\text { des gentlemen } \\
\text { des lieder }\end{array}$ & $\begin{array}{l}\text { Beberapa nomina yang } \\
\text { berasal dari bahasa Inggris, } \\
\text { Latin atau italia bervariasi } \\
\text { bentuk jamaknya }\end{array}$ \\
\hline $\begin{array}{l}\text { une Antille } \\
\text { l'Amérique }\end{array}$ & $\begin{array}{l}\text { des Antilles } \\
\text { les Amériques }\end{array}$ & $\begin{array}{l}\text { Bentuk jamak nama geografi } \\
\text { mempunyai ketentuan yang } \\
\text { sama dengan aturan umum }\end{array}$ \\
\hline
\end{tabular}

DIKSI Vol.10, No.2, Juli 2003 


\begin{tabular}{|l|l|l|}
\hline $\begin{array}{l}\text { les Condés } \\
\text { les Bourbon } \\
\text { les Hugos }\end{array}$ & $\begin{array}{l}\text { les Renoirs } \\
\text { les Watteaux } \\
\text { les Molière } \mathrm{d} \text { an }\end{array}$ & $\begin{array}{l}\text { Nama diri perorangan dapat } \\
\text { menjadi penanda jamak } \\
\text { apabila: }\end{array}$ \\
& $\begin{array}{l}\text { les Racine } \\
\end{array}$ & - Menggambarkan keluarga \\
& & kerajaan \\
& - Dipakai sebagai model \\
& & atau jenis \\
& & - Menggambarkan karya seni \\
& & seorang penulis \\
\hline
\end{tabular}

Tabel 4. Pembentukan kata majemuk (nom composé) berdasarkan jumlah

\begin{tabular}{|l|l|l|}
\hline Nomina Tunggal & Nomina Jamak & \multicolumn{1}{c|}{ Aturan } \\
\hline $\begin{array}{l}\text { un entresol } \\
\text { un gendarme }\end{array}$ & $\begin{array}{l}\text { des entresols } \\
\text { des gendarmes }\end{array}$ & $\begin{array}{l}\text { Aturan Umum: bentuk nomina } \\
\text { jamak dibentuk dengan } \\
\text { menambahkan s }\end{array}$ \\
\hline $\begin{array}{l}\text { un coffre-fort } \\
\text { une basse-cour }\end{array}$ & $\begin{array}{l}\text { des coffres-forts } \\
\text { des basses-cours }\end{array}$ & $\begin{array}{l}\text { 2. nomina gabungan ditulis } \\
\text { dalam bentuk jamak, jika: }\end{array}$ \\
\hline un château fort & des châteaux forts & $\begin{array}{l}\text { a) dibentuk dari adj + nomina } \\
\text { maka kedua nomina ditulis } \\
\text { dalam bentuk jamak }\end{array}$ \\
\hline $\begin{array}{l}\text { un chou-fleur } \\
\text { un chef-lieu }\end{array}$ & $\begin{array}{l}\text { des choux-fleurs } \\
\text { des chefs-lieux }\end{array}$ & $\begin{array}{l}\text { b) keduanya dalam bentuk } \\
\text { aposisi, maka keduanya ditulis } \\
\text { dalam bentuk jamak }\end{array}$ \\
\hline $\begin{array}{l}\text { une pomme de terre } \\
\text { un chef-d'auvre } \\
\text { un timbre-poste }\end{array}$ & $\begin{array}{l}\text { des pommes de terre } \\
\text { des timbres-poste }\end{array}$ & $\begin{array}{l}\text { c) jika dibentuk dari } \\
\text { nomina + pelengkap, dengan } \\
\text { atau tanpa preposisi, maka } \\
\text { kata pertama saja yang ditulis } \\
\text { dalam bentuk jamak }\end{array}$ \\
\hline
\end{tabular}




\begin{tabular}{|l|l|l|}
\hline $\begin{array}{l}\text { un avant-poste } \\
\text { un en-tête }\end{array}$ & $\begin{array}{l}\text { des avant-postes } \\
\text { des en-têtes }\end{array}$ & $\begin{array}{l}\text { d) dibentuk dari kata yang } \\
\text { tetap + sebuah nomina, maka } \\
\text { nominanya saja yang } \\
\text { berbentuk jamak }\end{array}$ \\
\hline $\begin{array}{l}\text { un va-et-vient } \\
\text { un tête-â-tête }\end{array}$ & $\begin{array}{l}\text { des va-et-vient } \\
\text { des tête-à-tête }\end{array}$ & $\begin{array}{l}\text { e) dibentuk dengan 2 (dua) } \\
\text { verba atau sebuah ekspresi, } \\
\text { maka kedua katanya bentuknya } \\
\text { tetap seperti bentuk tunggal }\end{array}$ \\
\hline $\begin{array}{l}\text { un abat-jour } \\
\text { un presse-purée } \\
\text { un gratte-ciel } \\
\text { un couvre-lit } \\
\text { un tire-bouchon }\end{array}$ & $\begin{array}{l}\text { des abat-jour } \\
\text { des presse-purée } \\
\text { des porte-plume } \\
\text { des gratte-ciel }\end{array}$ & $\begin{array}{l}\text { f) dibentuk dengan } \\
\text { verba + pelengkap, maka bentuk } \\
\text { jamaknya tidak mengalami } \\
\text { perubahan, demikian juga dalam } \\
\text { des tire-bouchons }\end{array}$ \\
$\begin{array}{l}\text { abat-lits porte-, presse } \\
\text { Kadang-kadang sejumlah } \\
\text { nomina gabungan tetap ditulis } \\
\text { dalam bentuk jamak }\end{array}$ \\
\hline $\begin{array}{l}\text { un garde-voie } \\
\text { des gardes-voie } \\
\text { des garde-boue }\end{array}$ & $\begin{array}{l}\text { g) nomina gabungan yang } \\
\text { dibentuk dengan kata garde } \\
\text { dapat mempunyai kategori } \\
\text { nomina atau verba. Jika berarti } \\
\text { nomina, maka kata yang } \\
\text { mengikutinya mempunyai } \\
\text { bentuk jamak yang tetap, namun } \\
\text { jika berkategori verba, maka } \\
\text { kata yang mengikutinya dapat } \\
\text { berbentuk tetap ataupun bentuk } \\
\text { jamak, bergantung pada } \\
\text { makna katanya. }\end{array}$ \\
\hline
\end{tabular}

DIKSI Vol.10, No.2, Juli 2003 


\begin{tabular}{|l|l|l|}
\hline $\begin{array}{l}\text { une grande-mère } \\
\text { un grand-père }\end{array}$ & $\begin{array}{l}\text { des grande-mères } \\
\text { des grands-pères }\end{array}$ & $\begin{array}{l}\text { h) dibentuk dengan nomina } \\
\text { gabungan dengan adj grand, } \\
\text { maka kata tersebut bentuk } \\
\text { jamaknya tidak berubah jika } \\
\text { diikuti oleh nomina jenis } \\
\text { femina, kecuali une } \\
\text { grande-duchesse, des } \\
\text { grandes-duchesses }\end{array}$ \\
\hline
\end{tabular}

\section{Adjektiva}

Adjektiva (l'adjectif qualificatif) adalah kata yang bersifat tidak tetap atau berubah-ubah (invariable) berdasarkan jumlah dan jenis nomina yang diterangkannya (Garde-Tamine, 1998:59 dan Jouannon, 1984: 72). Pembentukan adjektiva berdasarkan jenis dan jumlah nomina yang diterangkannya dapat dilihat pada tabel 5,6, dan 7 di bawah ini.

Tabel 5. Pembentukan Adjektiva Berdasarkan Jenis

\begin{tabular}{|c|c|c|}
\hline $\begin{array}{c}\text { Adjektiva } \\
\text { Maskula }\end{array}$ & $\begin{array}{l}\text { Adjektiva } \\
\text { Femina } \\
\end{array}$ & Aturan \\
\hline $\begin{array}{l}\text { un grand bureau } \\
\text { un hardi marin }\end{array}$ & $\begin{array}{l}\text { des grande échelle } \\
\text { une manouvre hard }\end{array}$ & $\begin{array}{l}\text { Aturan umum: bentuk femina } \\
\text { edengan menambahkan e pada } \\
\text { bentuk maskulanya }\end{array}$ \\
\hline un large trottoir & une rue large & $\begin{array}{l}\text { Jika pada bentuk maskulanya } \\
\text { berakhiran e, maka bentuk } \\
\text { feminanya tidak berubah }\end{array}$ \\
\hline un cri aigu & une pointe aiguë & $\begin{array}{l}\text { Jika bentuk maskulanya } \\
\text { berakhiran gu, maka bentuk } \\
\text { feminanya berakhiran -guë }\end{array}$ \\
\hline
\end{tabular}




\begin{tabular}{|l|l|l|}
\hline $\begin{array}{l}\text { un beau jouet } \\
\text { un terrain mou }\end{array}$ & $\begin{array}{l}\text { une belle gravure } \\
\text { une chair molle }\end{array}$ & $\begin{array}{l}\text { Jika bentuk maskulanya } \\
\text { berakhiran eau, -ou, maka jenis } \\
\text { feminanya berakhiran - } \\
\text { elle, -olle, kecuali kata-kata flou, } \\
\text { hindou jenis feminanya } \\
\text { menjadi floue, hindoue }\end{array}$ \\
\hline $\begin{array}{l}\text { un cruel ennemi } \\
\text { un pareir nul espoir }\end{array}$ & $\begin{array}{l}\text { une farce cruelle } \\
\text { une note nulle } \\
\text { une vie pareille }\end{array}$ & $\begin{array}{l}\text { Jika bentuk maskulanya } \\
\text { berakhiran el, -ul, -l, maka jenis } \\
\text { feminanya berakhiran } \\
\text {-elle, -ulle, -ille }\end{array}$ \\
\hline $\begin{array}{l}\text { un château ancien } \\
\text { un bon numéro }\end{array}$ & $\begin{array}{l}\text { une bague ancienne bonneb affaire } \\
\text { une }\end{array}$ & $\begin{array}{l}\text { Jika bentuk maskulanya } \\
\text { berakhiran ien, -ion, -on, } \\
\text { maka jenis feminanya } \\
\text { berakhiran ienne, -ionne, -onne }\end{array}$ \\
\hline $\begin{array}{l}\text { l'esprit partisan } \\
\text { le labeur paysan }\end{array}$ & $\begin{array}{l}\text { une querelle } \\
\text { partisane } \\
\text { la vie paysanne }\end{array}$ & $\begin{array}{l}\text { Jika bentuk maskulanya } \\
\text { berakhiran an maka jenis } \\
\text { feminanya berakhiran ane, } \\
\text { kecuali paysan yang feminanya } \\
\text { menjadi paysanne }\end{array}$ \\
\hline $\begin{array}{l}\text { un élève muet } \\
\text { un conte idiot }\end{array}$ & $\begin{array}{l}\text { une douleur muette } \\
\text { une farce idiote } \\
\text { une sotte réponse }\end{array}$ & $\begin{array}{l}\text { Jika bentuk maskulanya } \\
\text { berakhiran et, maka jenis } \\
\text { feminanya berakhiran ette, } \\
\text { namun ajd berakhiran ot } \\
\text { feminanya menjadi ote, } \\
\text { kecuali pada boulot, maigriot, } \\
\text { palot, sot, vieillot berakhiran } \\
\text {-otte }\end{array}$ \\
\hline $\begin{array}{l}\text { l'âme inquiète } \\
\text { Adj seperti complet, désuet, } \\
\text { iscret, indiscret, incomplet, } \\
\text { inquiet, secret, feminanya } \\
\text { berakhiran -ète }\end{array}$ \\
\hline
\end{tabular}

DIKSI Vol.10, No.2, Juli 2003 


\begin{tabular}{|l|l|l|}
\hline $\begin{array}{l}\text { un bois épais } \\
\text { un billet faux }\end{array}$ & $\begin{array}{l}\text { une encre épaisse } \\
\text { une pièce fausse }\end{array}$ & $\begin{array}{l}\text { Bentuk maskula bas, épais, } \\
\text { gros, faux, roux, las, exprès, } \\
\text { métis bentuk feminanya } \\
\text { berakhiran sse }\end{array}$ \\
\hline $\begin{array}{l}\text { le dernier mot } \\
\text { un léger retard }\end{array}$ & $\begin{array}{l}\text { la dernière page } \\
\text { une banque légère }\end{array}$ & $\begin{array}{l}\text { Jika bentuk maskulanya } \\
\text { berakhiran er, maka feminanya } \\
\text { berakhiran ère }\end{array}$ \\
\hline $\begin{array}{l}\text { un garçon sérieux } \\
\text { un enfant jaloux }\end{array}$ & $\begin{array}{l}\text { une idée sérieuse } \\
\text { une fille jalouse } \\
\text { une réponse } \\
\text { trampeuse } \\
\text { une meilleure } \\
\text { façon meilleur avis }\end{array}$ & $\begin{array}{l}\text { Jika bentuk maskulanya } \\
\text { berakhiran eux, -oux, -eur, } \\
\text { maka jenis feminanya } \\
\text { berakhiran euse, -ouse, -euse } \\
\text { kecuali kata-kata meilleur, } \\
\text { inférieur, antérier, majeur, } \\
\text { mineur, supérieur, ultérieur, } \\
\text { maka bentuk feminanya } \\
\text { berakhiran -e }\end{array}$ \\
\hline un nom évocateur & $\begin{array}{l}\text { une phrase } \\
\text { évocatrice }\end{array}$ & $\begin{array}{l}\text { Jika bentuk maskulanya } \\
\text { berakhiran teur maka bentuk } \\
\text { feminanya secara umum } \\
\text { berakhiran -trice }\end{array}$ \\
\hline un froid vif & une vive répartie & $\begin{array}{l}\text { Jika bentuk maskulanya } \\
\text { berakhiran f, maka bentuk } \\
\text { feminanya berakhiran -v }\end{array}$ \\
\hline
\end{tabular}


Tabel 6. Pembentukan Adjektiva Takberaturan Berdasarkan Jenis*

\begin{tabular}{|l|l|}
\hline Jenis Maskula & Jenis Femina \\
\hline blanch & blanche \\
franc & franche \\
frais & fraîche \\
sec & sèche \\
doux & douce \\
tiers & tierce \\
long & longue \\
favori & favorite \\
coi & coite \\
malin & maligne \\
bénin & bénigne \\
vieux & vieielle \\
hébreu & hébraïque \\
pécheur & pécheresse \\
maître & maîtresse \\
traïtre & traïtresse \\
vengeur & vengeresse \\
caduc & caduque \\
grec & grecque \\
turc & turque \\
andalou & andalouse \\
\hline
\end{tabular}

* Catatan: Yang sudah dapat ditemukan oleh penulis dan ikonsultasikan dengan buku: dapat diteliti lebih lanjut. 
Tabel 7. Pembentukan Adjektiva Berdasarkan Jumlah

\begin{tabular}{|c|c|c|}
\hline $\begin{array}{c}\text { Adjektiva } \\
\text { Tunggal }\end{array}$ & $\begin{array}{c}\text { Adjektiva } \\
\text { Jamak }\end{array}$ & Aturan \\
\hline $\begin{array}{l}\text { un grand cahier } \\
\text { un phrase brève }\end{array}$ & $\begin{array}{l}\text { des grands espoirs } \\
\text { de brèves phrases }\end{array}$ & $\begin{array}{l}\text { Aturan Umum: bentuk } \\
\text { adjektiva jamak dibentuk } \\
\text { dengan menambahkan } \mathbf{s} \\
\text { pada bentuk tunggalnya }\end{array}$ \\
\hline $\begin{array}{l}\text { un temps gris } \\
\text { un faux passepor }\end{array}$ & $\begin{array}{l}\text { des murs gris } \\
\text { de faux papiers }\end{array}$ & $\begin{array}{l}\text { Jika adj tunggalnya } \\
\text { berakhiran }-\mathrm{s} \text { atau } \mathrm{x}, \text { maka } \\
\text { bentuk jamaknya tidak } \\
\text { berubah }\end{array}$ \\
\hline $\begin{array}{l}\text { un tigre royal } \\
\text { le mot final }\end{array}$ & $\begin{array}{l}\text { des tigres royaux } \\
\text { les combats finals }\end{array}$ & $\begin{array}{l}\text { Jika bentuk adj tunggal } \\
\text { berakhiran al, maka bentuk } \\
\text { jamaknya berakhiran aux, } \\
\text { kecuali pada banal, bancal, } \\
\text { fatal, final, glacial, natal, } \\
\text { tonal, banal, bancal, fatal, } \\
\text { final, glacial, natal, tonal, } \\
\text { yang berakhiran -als }\end{array}$ \\
\hline un beau jouet & De beaux jouets & $\begin{array}{l}\text { Adj maskula seperti beau, } \\
\text { jumeau, nouveau, manceau, } \\
\text { tourangeau, hébreu bentuk } \\
\text { jamak feminanya } \\
\text { berakhiran } \mathrm{x}\end{array}$ \\
\hline
\end{tabular}

\section{Verba}

Verba adalah kata yang selalu berubah-ubah bentuknya, yang menyatakan kegiatan yang dilakukan atau dialami oleh subjek (verbe d'action) atau yang menunjukkan keadaan (verbe d'état) (Jouannon, 
1984:144). Perubahan bentuk pada verba yang dikenal dengan istilah konjugasi tersebut, selain ditentukan oleh jenis dan jumlah nomina sebagai subjek, juga dipengaruhi oleh kala dan modus (temps et mode). Kala adalah pembedaan bentuk verba untuk menyatakan perbedaan waktu atau jangka waktu perbuatan atau keadaan. Biasanya dibedakan menjadi kala lampau, kala kini, dan kala mendatang (Kridalaksana, 2001: 92). Modus (mode) adalah kategori gramatikal dalam bentuk verba yang mengungkapkan suasana psikologis perbuatan menurut tafsiran pembicara atau sikap pembicara tentang apa yang diucapkannya (ibid: 139). Dengan demikian, akhiran (desinence) yang terdapat pada konjugasi verba dapat menunjukkan jenis, jumlah, kala, dan modus, (bahkan juga aspek). Misalnya: bentuk verba infinitif: acheter 'membeli' dapat dikonjugasikan antara lain menjadi: achètent, achetait, achètes. dan seterusnya. Yang digarisbawahi adalah akhiran (desinence) yang dapat dijelaskan sebagai berikut.

\begin{tabular}{|l|l|l|l|}
\hline Bentuk desinence & ent & ait & es \\
\hline Jenis (personne) & Orang ketiga (ils) & Orang ketiga (il) & Orang kedua (tu) \\
\hline Jumlah & jamak & tunggal & tunggal \\
\hline kala & kini & lampau (imparfait) & kini \\
\hline modus & indikatif & indikatif & Indikatif \\
\hline
\end{tabular}

Verba dalam bahasa Prancis diklasifikasikan menjadi 3 (tiga) kelompok besar (L'art de conjuger, 1980:7), yaitu: 1) kelompok verba yang bentuk infinitifnya berakhiran er dan jika dikonjugasikan pada orang pertama tunggal kala kini, modus indikatif akan berakhiran e, misalnya aimer $\longrightarrow j^{\prime}$ aime, 2) kelompok verba yang bentuk infinitifnya berakhiran ir, yang jika dikonjugasikan pada orang pertama tunggal kala kini modus indikatif akan berakhiran is , yang participe presentnya berakhiran issant, misalnya finir $\longrightarrow$ je finis; finissant, 
dan 3) sisanya, yaitu verba yang tidak masuk kelompok 1 (satu) juga kelompok 2 (dua), seperti: 1) verba aller, 2) verba berakhiran ir yang tidak termasuk dalam kategori 2 (dua), misalnya partir, venir, cueillir, dan 3) verba yang bentuk infinitifnya berakhiran oir, -re, misalnya recevoir, rendre. Jadi kelompok 1 (satu) dan 2 (dua) termasuk verba yang beraturan, sedangkan kelompok 3 (tiga) termasuk kelompok verba takberaturan.

Adanya pengelompokan verba menjadi 3 (tiga) tersebut berakibat pula pada perbedaan akhiran (desinence) dalam konjugasinya. Pada tabel 8 berikut ini dapat dilihat bentuk akhiran (desinence) verba berdasarkan kelompok jumlah nomina sebagai subjeknya, kala dan modus.

Tabel 8. Akhiran (desinence) Verba Bahasa Prancis

\begin{tabular}{|c|c|c|c|c|c|c|c|c|c|}
\hline \multicolumn{5}{|c|}{ Indicatif ( kini) } & \multicolumn{5}{|c|}{ subjonctif (kini) } \\
\hline $\mathbf{s}$ & Kel 1 & Kel 2 & \multicolumn{2}{|c|}{ Kel 3} & $\mathbf{s}$ & Kel 1 & Kel 2 & \multicolumn{2}{|c|}{ Kel 3} \\
\hline $\mathrm{Je}$ & $-e$ & -is & $-s(x)$ & & $\mathrm{Je}$ & $-e$ & -isse & \multicolumn{2}{|l|}{$-e$} \\
\hline $\mathrm{Tu}$ & $-\mathrm{es}$ & -is & $-s(x)$ & -es & $\mathrm{Tu}$ & -es & -isses & \multicolumn{2}{|l|}{-es } \\
\hline $\begin{array}{l}\text { IV/ } \\
\text { elle }\end{array}$ & $-e$ & -it & $-t(d)$ & $-e$ & $\begin{array}{l}\text { I1/ } \\
\text { elle }\end{array}$ & $-e$ & -isse & \multicolumn{2}{|l|}{-e } \\
\hline Nous & -ons & -issons & -ons & -ons & \begin{tabular}{|l|} 
Nous \\
\end{tabular} & -ons & -issions & \multicolumn{2}{|l|}{-ions } \\
\hline Vous & $-e z$ & -issez & $-\mathrm{ez}$ & $-\mathrm{ez}$ & \begin{tabular}{|l|} 
Vous \\
\end{tabular} & $-\mathrm{ez}$ & -issiez & \multicolumn{2}{|l|}{-iez } \\
\hline $\begin{array}{l}\text { Ils/ } \\
\text { elles }\end{array}$ & -ent & -issent & -ent (nt) & -ent & $\begin{array}{l}\text { Ils/ } \\
\text { elles }\end{array}$ & -ent & -issent & \multicolumn{2}{|l|}{-ent } \\
\hline \multicolumn{5}{|c|}{ Indicatif (Imparfait) } & \multicolumn{5}{|c|}{ subjonctif (Imparfuit) } \\
\hline$\overline{\mathbf{S}}$ & $\overline{\text { Kel } 1}$ & Kel 2 & \multicolumn{2}{|c|}{ Kel 3} & $\bar{s}$ & Kel 1 & Kel 2 & \multicolumn{2}{|c|}{ Kel 3} \\
\hline $\mathrm{Je}$ & -ais & -issais & \multicolumn{2}{|l|}{-ais } & $\mathrm{Je}$ & -esse & -isse & -isse & -usse \\
\hline $\mathrm{Tu}$ & -ais & -issais & \multicolumn{2}{|l|}{-ais } & $\mathrm{Tu}$ & -esses & -isses & \multirow{2}{*}{$\begin{array}{l}-\mathrm{isses} \\
\hat{\mathrm{i} t}\end{array}$} & -usses \\
\hline $\begin{array}{l}\text { II/ } \\
\text { elle }\end{array}$ & -ait & -issait & \multicolumn{2}{|l|}{-ait } & $\begin{array}{l}1 / / \\
\text { elle }\end{array}$ & ât & -ît & & -ût \\
\hline Nous & -ions & -issions & \multicolumn{2}{|l|}{-ions } & Nous & -assions & -issions & -issions & -ussions \\
\hline Vous & -iez & -issiez & \multicolumn{2}{|l|}{-iez } & Vous & -assiez & -issiez & \multirow{2}{*}{$\frac{\text {-issiez }}{\text {-issent }}$} & -ussiez \\
\hline $\begin{array}{l}\text { Ils/ } \\
\text { elles }\end{array}$ & -aient & -issaient & \multicolumn{2}{|l|}{-aient } & $\begin{array}{l}\text { Ils/ } \\
\text { elles }\end{array}$ & -assent & -issent & & -ussent \\
\hline
\end{tabular}

Pembentukan Kata dalam Bahasa Perancis (Siti Perdi Rahayu) 


\begin{tabular}{|c|c|c|c|c|c|c|c|c|c|}
\hline \multicolumn{5}{|c|}{ Indicatif (Lampau) } & \multicolumn{5}{|c|}{ Imperatif (Kini) } \\
\hline $\mathbf{s}$ & Kel 1 & Kel 2 & \multicolumn{2}{|c|}{ Kel 3} & $\mathbf{s}$ & Kel 1 & Kel 2 & \multicolumn{2}{|c|}{ Kel 3} \\
\hline $\mathrm{Je}$ & -ai & -is & -is & -us & $\mathrm{Je}$ & & & & \\
\hline $\mathrm{Tu}$ & -as & -is & -is & -us & $\mathrm{Tu}$ & $-\mathrm{e}$ & -is & $-S$ & $-\mathrm{e}$ \\
\hline $\begin{array}{l}\text { IV } \\
\text { elle }\end{array}$ & $-a$ & $-\mathrm{it}$ & -it & -ut & $\begin{array}{l}\text { IV/ } \\
\text { elle }\end{array}$ & & & & \\
\hline Nous & -âmes & -îmes & -îmes & -ûmes. & Nous & -ons & -issons & -ons & -ons \\
\hline Vous & -âtez & -îtes & -îtes & -ûtes & Vous & $-\mathrm{ez}$ & -issez & $-e z$ & $-\mathrm{ez}$ \\
\hline $\begin{array}{l}\text { Ils/ } \\
\text { elles }\end{array}$ & -èrent & -irent & -irent & -urent & $\begin{array}{l}\text { Ils/ } \\
\text { elles }\end{array}$ & & & & \\
\hline \multicolumn{5}{|c|}{ Indicatif (masa yang akan datang) } & \multicolumn{5}{|c|}{ Conditionnel (Kini) } \\
\hline $\mathbf{s}$ & Kel 1 & Kel 2 & \multicolumn{2}{|c|}{ Kel 3} & $\mathbf{S}$ & Kel 1 & Kel 2 & \multicolumn{2}{|c|}{ Kel 3} \\
\hline Je & -erai & -irai & \multicolumn{2}{|l|}{...rai } & $\mathrm{Je}$ & -erais & -irais & -isse & ...rais \\
\hline $\mathrm{Tu}$ & -eras & -iras & \multicolumn{2}{|l|}{...ras } & $\mathrm{Tu}$ & -erais & -irais & -isses & ...rais \\
\hline $\begin{array}{l}\text { Il/ } \\
\text { elle }\end{array}$ & -era & -ira & \multicolumn{2}{|l|}{...ra } & $\begin{array}{l}\text { Il/ } \\
\text { elle }\end{array}$ & -erait & -irait & $-\hat{1} t$ & ...rait \\
\hline Nous & -erons & -irons & \multicolumn{2}{|c|}{...rons } & Nous & -erions & -iriions & -issions & ...rions \\
\hline Vous & -erez & -irez & \multicolumn{2}{|l|}{$\ldots \mathrm{rez}$} & Vous & -eriez & -iriez & -issiez & ...riez \\
\hline $\begin{array}{l}\text { Ils/ } \\
\text { elles }\end{array}$ & -eront & -iront & \multicolumn{2}{|l|}{...ront } & $\begin{array}{l}\text { Ils/ } \\
\text { elles }\end{array}$ & -eraient & -iraent & -issent & ...raient \\
\hline
\end{tabular}

\section{Penutup}

Dari uraian di atas dapat disimpulkan bahwa pembentukan kata dalam bahasa Prancis dapat terjadi melalui 2 (dua) cara, yaitu 1) pembentukan kata yang dapat mengubah kategori dan atau identitas kata atau disebut pembentukan kata secara derivatif, dan 2) pembentukan kata yang tidak mengubah kategori kata atau disebut pembentukan kata secara inflektif. Cara pertama dapat dilakukan dengan a) derivasi, yang meliputi derivaso zero (dérivation impropre) dan afiksasi (dérivation propre) yang meliputi prefiksasi, sufiksasi, dan konfiks, b) komposisi atau pemajemukan, c) abrevisasi, d) onomatope, dan e) serapan.

Cara yang kedua, yaitu pembentukan kata yang tidak akan mengubah kategori kata. Cara ini hanya dapat terjadi pada kategori nomina, adjektiva, dan verba. Pembentukan nomina yang tidak mengubah kategori dilakukan berdasarkan jenis (genre) dan jumlah (nombre). Jenis meliputi maskula dan femina, sedangkan jumlah 
meliputi jumlah tunggal dan jamak. Pembentukan adjektiva juga harus disesuaikan dengan jenis (maskula/ femina) dan.jumlah (tunggal/ jamak) nomina yang diterangkannya. Perubahan bentuk verba harus selalu disesuaikan dengan nomina subjeknya, kala dan modus.

\section{DAFTAR PUSTAKA}

Bescherelle, L.N. 1980. L'art de Conjuguer: Dictionnaire de 2000 verbes. Paris: Hatier.

Blois, J. M. B. 1975. Notre Langue Française. Bruxelle-MontréalParis: Marcel Didier

Certa, P. Le Français d'aujourd'hui: Une langue qui bouge. Seri France Info. Paris: Radio France et Balland/ Jacob-Duvernet.

Gardes-Tamine, J. 1998. la Grammaire: 1. Phonologie, morphologie, lexicologi. Paris: Armand Colin.

Garrie, N. 2001. Introduction à la Linguistique. Paris: Hachette

Grevisse, M. 1969. Précis de Grammaire Française. Paris-Gembloux: Duculot

Jouannon, G. et Jean, D. 1984. Grammaire et Exercices de Français. Paris: Librairie Larousse.

Kridalaksana, H. 1996. Pembentukan Kata dalam Bahasa Indonesia. Jakarta: P.T. Gramedia Pustaka Utama. . 2001. Kamus Linguistik. Jakarta: PT. Gramedia 